Canadian

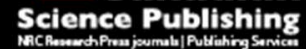

Canadian Journal of Microbiology Revue canadienne de de microbiologie

\title{
Expression, purification and renaturation of recombinant peptide-based HIV vaccine in Escherichia coli
}

\begin{tabular}{|c|c|}
\hline Journal: & Canadian Journal of Microbiology \\
\hline Manuscript ID & cjm-2016-0528.R1 \\
\hline Manuscript Type: & Article \\
\hline Date Submitted by the Author: & $10-N o v-2016$ \\
\hline Complete List of Authors: & $\begin{array}{l}\text { He, Wei; East China University of Science and Technology, State Key } \\
\text { Laboratory of Bioreactor Engineering } \\
\text { Shu, Jiayi; Chinese Academy of Sciences, Shanghai, China, Institut Pasteur } \\
\text { of Shanghai } \\
\text { Zhang, Jian; East China University of Science and Technology, State Key } \\
\text { Laboratory of Bioreactor Engineering } \\
\text { Liu, Zhihua; Chinese Academy of Sciences, Shanghai, China, Institut } \\
\text { Pasteur of Shanghai } \\
\text { Xu, Jianqing; Fudan University, Key Laboratory of Medical Molecular } \\
\text { Virology of Ministry of Education/Health } \\
\text { Jin, Xia; Chinese Academy of Sciences, Shanghai, China, Institut Pasteur of } \\
\text { Shanghai } \\
\text { Wang, Xuedong; East China University of Science and Technology, State } \\
\text { Key Laboratory of Bioreactor Engineering }\end{array}$ \\
\hline Keyword: & $\begin{array}{l}\text { epitope-peptide-based HIV vaccine, prokaryotic expression, inclusion body, } \\
\text { purification, immunogenicity }\end{array}$ \\
\hline
\end{tabular}

\section{SCHOLARONE \\ Manuscripts}




\section{Expression, purification and renaturation of recombinant peptide-based HIV} vaccine in Escherichia coli

Wei He, Jiayi Shu, Jian Zhang, Zhihua Liu, Jianqing Xu, Xia Jin*, Xuedong Wang*

W. He, J. Zhang, and X. D. Wang. State Key Laboratory of Bioreactor Engineering, New World Institute of Biotechnology, East China University of Science and Technology, 130 Meilong Road, Shanghai 200237, P.R. China

J. Y. Shu and Z. H. Liu. Institut Pasteur of Shanghai, Chinese Academy of Sciences, Shanghai 200031, P.R. China; Shanghai Public Health Clinical Center and Institutes of Biomedical Sciences, Key Laboratory of Medical Molecular Virology of Ministry of Education/Health, Fudan University, Shanghai 200030, P.R. China

J. Q. Xu. Shanghai Public Health Clinical Center and Institutes of Biomedical Sciences, Key Laboratory of Medical Molecular Virology of Ministry of Education/Health, Fudan University, Shanghai 200030, P.R. China

X. Jin. Institut Pasteur of Shanghai, Chinese Academy of Sciences, Shanghai 200031, P.R. China

*Corresponding authors: Xuedong Wang (E-mail: xdwang@ecust.edu.cn); Xia Jin (E-mail: xjin@ips.ac.cn) 


\section{Abstract}

Based on the new HIV vaccine strategy of designing epitope-based immunogen, we previously predicted 20 potential HIV epitopes using bioinformatics approaches. The combination of these 20 epitopes has a theoretical coverage of $98.1 \%$ of the population for both the prevalent HIV genotypes and Chinese human leukocyte antigen (HLA) DR types. In order to test the immunogenicity of this vaccine in vivo, a corresponding antigen needs to be prepared. To this end, we constructed a recombinant plasmid containing DNA encoding 300 amino acids of this vaccine protein and a 6-His tag for verification of protein expression and ease of purification, and then transformed E. coli cells with the plasmid. After IPTG induction, the recombinant protein was expressed in the form of mainly inclusion bodies. To stabilize the structure of denatured inclusion bodies for efficient purification and renaturation in vitro, we transferred the dissolved inclusion bodies from $7 \mathrm{M}$ guanidine- $\mathrm{HCl}$ to $8 \mathrm{M}$ urea. Under denaturing conditions, the vaccine protein was purified by a three-step process including ion-exchange chromatography and affinity column, and then renatured by stepwise dialysis. Together, the above described procedures generated $43 \mathrm{mg}$ of vaccine protein per liter of fermentation medium, and the final product reached approximately $95 \%$ purity. The purified protein was capable of eliciting antigen-specific $\mathrm{T}$ cell responses in immunized mice.

Keywords: epitope-peptide-based HIV vaccine; prokaryotic expression; inclusion body; purification; immunogenicity 


\section{Introduction}

Human immunodeficiency virus (HIV) ${ }^{1}$ is known to have a high mutation rate and sequence diversity (De Groot et al. 2003; van der Kuyl et al. 2012). It has been difficult to develop a successful HIV vaccine to induce broadly neutralizing antibodies (bNAb) or elicit multifunctional T cells to prevent infection (Mcmichael et al. 2010; Walker et al. 2008). CD4+ $\mathrm{T}$ cells are central to the induction and maintenance of CD8+ T cell and antibody-producing B cell responses, both of which are conceptually essential for protection against the acquisition of HIV infection or the progression of HIV disease (Buchbinder et al. 2008; McElrath et al. 2008). Thus how to design a vaccine to induce specific $\mathrm{CD} 4+\mathrm{T}$ cell responses to $\mathrm{HIV}$ is an intensely studied area of HIV vaccine research. Using epitope-based immunogen to stimulate CD4+ T cell responses is one of many new HIV vaccine strategies (Barouch et al. 2013; Fischer et al. 2007; Haynes 2015; Hulot et al. 2015; Korber et al. 2009; Kulkarni et al. 2014; Létourneau et al. 2007; Mothe et al. 2015).

We have previously designed a peptide-based vaccine (Shu et al. 2014) that targets specifically Chinese by first assembling a database that is comprised of sequences from 821 Chinese HIV isolates and 46 human leukocyte antigen (HLA) DR alleles identified in the Chinese population (Gonzalez-Galarza et al. 2011; Kuiken et al.

\footnotetext{
${ }^{1}$ Abbreviations used: HIV, human immunodeficiency virus; bNAb, broadly neutralizing antibodies; HLA, human leukocyte antigen; LB, Luria Bertani; IPTG, isopropyl- $\beta$-D-thiogalactopyranoside; SDS-PAGE, sodium dodecyl sulfate polyacrylamide gel electrophoresis; PBS, phosphate buffered saline; mAb, monoclonal antibody; IEC, ion-exchange chromatography.
} 
2003). This candidate vaccine is comprised of 20 predicted HIV epitopes, that in combination covers $98.1 \%$ of the Chinese population for both the prevalent HIV genotypes and Chinese HLA-DR types (Bui et al. 2005; Lu et al. 2006; Nielsen et al. 2009; Nielsen et al. 2008; Nielsen et al. 2007; Sturniolo et al. 1999; Vita et al. 2010; Walker et al. 2009; Wang et al. 2010).

In the present study, an efficient process was developed to produce highly purified recombinant HIV T helper vaccine using an Escherichia coli expression system. The recombinant vaccine was expressed in the form of inclusion bodies that were subsequently purified under denaturing conditions, and then refolded through stepwise dialysis. The final purity of recombinant HIV vaccine protein was approximately $95 \%$, and the quantity of production was $43 \mathrm{mg}$ per liter of fermentation medium, and thus the described processes were commensurate with the requirement for large-scale production. Finally, we demonstrated that the purified protein product was capable of eliciting peptide-specific $\mathrm{T}$ cell responses in immunized mice.

\section{Materials and methods}

\section{Cloning and expression of the recombinant protein}

According to the amino acid sequence of the predicted peptide-based HIV vaccine (Shu et al. 2014), DNA encoding the peptides and GPGPG spacers was artificially synthesized (Generay, Shanghai, China) with codon optimized for expression in E. coli. Restriction sites of EcoR I and Not I were introduced to the forward and reverse 
primers, respectively. Taq DNA Polymerase (Takara Biotech, Dalian, China) was used for PCR amplification. Purified PCR segments were inserted into pET-30a(+) vector (Novagen, USA) that had been digested with the same restriction enzymes. The recombinant plasmid was used to transform competent E. coli BL21 (DE3) cells (CWbio, Beijing, China).

The positive colonies of transformed E. coli BL21 (DE3) were selected and then cultivated in Luria-Bertani (LB) medium (tryptone $10 \mathrm{~g} / \mathrm{L}$, yeast extract $5 \mathrm{~g} / \mathrm{L}, \mathrm{NaCl} 10$ $\mathrm{g} / \mathrm{L})$ supplemented with kanamycin $(100 \mu \mathrm{g} / \mathrm{mL})$ at $37{ }^{\circ} \mathrm{C}$ and $200 \mathrm{rpm}$. When the $\mathrm{OD}_{600}$ reached $0.4-0.8$, the cells were induced with $0.1 \mathrm{mM}$ isopropyl- $\beta-\mathrm{D}-$ thiogalactopyranoside (IPTG) for $12 \mathrm{~h}$ at $37^{\circ} \mathrm{C}$. Then, the cultures were centrifuged, and the pellets were processed for sodium dodecyl sulfate polyacrylamide gel electrophoresis (SDS-PAGE) analysis (Laemmli 1970).

\section{Fed-batch fermentation of recombinant strain}

A single cryovial of working culture was inoculated into $30 \mathrm{~mL}$ of LB medium with $100 \mu \mathrm{g} / \mathrm{mL}$ kanamycin and grown for $5 \mathrm{~h}$ at $37^{\circ} \mathrm{C}$ on an orbital shaker (ZQLY-180, Zhichu Instrument, Shanghai, China) at $200 \mathrm{rpm}$. The culture (10 mL) was transferred into $500 \mathrm{~mL}$ flasks containing $100 \mathrm{~mL}$ of fermentation media (media composition per L: $10 \mathrm{~g}$ glucose, 10 g tryptone, 20 g yeast extract, $4 \mathrm{~g} \mathrm{~K}_{2} \mathrm{HPO}_{4}, 2 \mathrm{~g} \mathrm{KH}_{2} \mathrm{PO}_{4}, 7 \mathrm{~g} \mathrm{Na}_{2} \mathrm{HPO}_{4}$, $1.2 \mathrm{~g}\left(\mathrm{NH}_{4}\right)_{2} \mathrm{SO}_{4}, 1 \mathrm{~g} \mathrm{MgSO}_{4}, 10 \mathrm{mg}$ kanamycin) and grown at $37^{\circ} \mathrm{C}$ and $200 \mathrm{rpm}$ for 5 h. This culture was used to inoculate a $7 \mathrm{~L}$ fermenter (Bxbio, Shanghai, China) with $4 \mathrm{~L}$ of fermentation media. Fermentation was carried out in $\mathrm{pH}$-stat fed-batch mode, using glycerol as the carbon source in feeding media (feeding media per L: 50\% glycerol, 40 
$\mathrm{g}$ tryptone, $30 \mathrm{~g}$ yeast extract). The $\mathrm{pH}$ was maintained at 7.0 with ammonium hydroxide. The flow of inlet air to the fermenter was set at $0.4 \mathrm{~L} / \mathrm{min}$. Stirrer speed was set at $300 \mathrm{rpm}$ and temperature was $37^{\circ} \mathrm{C}$. After $3 \mathrm{~h}$ of cultivation, when the DO level fell to $50 \%$ or below, the stirrer speed was increased in steps of $100 \mathrm{rpm}$ up to maximum of $800 \mathrm{rpm}$. As the $\mathrm{pH}$ began to rise (about $4 \mathrm{~h}$ of cultivation), additional feeding media was added with a rate of $0.5 \mathrm{~mL} / \mathrm{min}$ to hold the $\mathrm{pH}$ at 7.0 . When the $\mathrm{OD}_{600}$ reached $15-20$, the cells were induced with $0.1 \mathrm{mM}$ IPTG for $12 \mathrm{~h}$ at $37^{\circ} \mathrm{C}$. Then, the broth was harvested and centrifuged at $1600 \mathrm{~g}$ for $10 \mathrm{~min}$ at $4{ }^{\circ} \mathrm{C}$.

\section{Pretreatment of inclusion bodies}

The cell pellets obtained from fermentation culture were washed twice in phosphate buffer $\left(\mathrm{Na}_{2} \mathrm{HPO}_{4} 1.56 \mathrm{~g} / \mathrm{L}, \mathrm{NaH}_{2} \mathrm{PO}_{4} 0.2 \mathrm{~g} / \mathrm{L}\right)$ and resuspended in washing buffer (20 mM Tris, 1 mM EDTA, 0.5 M Urea, $1 \mathrm{M} \mathrm{NaCl,} \mathrm{0.4 \%} \mathrm{Triton} \mathrm{X-100,} \mathrm{pH} \mathrm{8.0)}$ with $10 \%-20 \%$ of cell concentration. The suspension was crushed by High Pressure Homogenizer (Union-Biotech, Shanghai, China) at the pressure of 800 bar. After three cycles, the crushed pellets were centrifuged at $4000 \mathrm{~g}$ for $60 \mathrm{~min}$ and the inclusion bodies were collected. Then, inclusion bodies were washed twice in washing buffer and harvested by centrifugation at $3500 \mathrm{~g}$ for $30 \mathrm{~min}$.

\section{Denaturation of inclusion bodies}

The washed inclusion bodies were dissolved in denaturation buffer $(20 \mathrm{mM}$ Tris, $50 \mathrm{mM} \beta$-mercaptoethanol, $7 \mathrm{M}$ guanidine- $\mathrm{HCl}, \mathrm{pH} 8.0)$ with the ratio of $1: 7(\mathrm{~g} / \mathrm{mL})$ and agitated at room temperature for $2 \mathrm{~h}$. After centrifugation at $3500 \mathrm{~g}$ for $30 \mathrm{~min}$, the 
supernatant was diluted with the buffer A $(20 \mathrm{mM}$ Tris- $\mathrm{HCl}, 8 \mathrm{M}$ urea, $\mathrm{pH} 8.0)$ to reduce the concentration of guanidine- $\mathrm{HCl}$ to $1 \mathrm{M}$.

\section{Purification and refolding of proteins obtained from inclusion bodies}

The denatured inclusion bodies were passed through $0.45 \mu \mathrm{m}$ filter membrane (Millipore, Billerica, USA) to remove aggregates. The filtrate was loaded onto $5 \mathrm{~mL}$ HisTrap FF column (Ni Sepharose 6 Fast Flow, GE healthcare, Fairfield, USA) that equilibrated with buffer A containing $50 \mathrm{mM}$ imidazole. Binding capacity of HisTrap FF was $200 \mathrm{mg}$ per milliliter of packing. The unbound proteins were washed with equilibration buffer. The bound proteins were eluted with $500 \mathrm{mM}$ imidazole in buffer A at a flow rate of $15 \mathrm{CV} / \mathrm{h}$, and then collected according to the absorbance of the eluents determined by an online UV-monitor (ZHD, ZhiMing Bio, Nanjing, China). The fractions with target proteins were precipitated with $30 \%$-saturation $\left(\mathrm{NH}_{4}\right)_{2} \mathrm{SO}_{4}$ to remove imidazole. After centrifugation at $3500 \mathrm{~g}$ for $30 \mathrm{~min}$, the protein precipitation was collected and redissolved in buffer A. Then the redissolved protein solution was loaded onto chromatography column containing cation exchanger (5 mL Hitrap CM FF, GE healthcare, Fairfield, USA) with a binding capacity of $250 \mathrm{mg}$ per milliliter of packing. After loading and washing, the bound proteins were eluted with buffer A containing a linear gradient of $0.1-1 \mathrm{M} \mathrm{NaCl}$ at a flow rate of $20 \mathrm{CV} / \mathrm{h}$.

In order to further improve the purity of target protein, $5 \mathrm{~mL}$ HisTrap column with Ni Sepharose High Performance (GE healthcare, Fairfield, USA) was used for purification of the recombinant protein vaccine. The binding capacity of HisTrap HP was $200 \mathrm{mg}$ per milliliter of packing. Similar to the process on HisTrap FF column, the 
bound proteins were eluted with buffer A containing 100-500 $\mathrm{mM}$ imidazole at a flow rate of $15 \mathrm{CV} / \mathrm{h}$.

The purified recombinant protein under denaturing conditions was stepwise dialyzed at $4{ }^{\circ} \mathrm{C}$ with the following refolding buffers: (1) buffer B (4 M urea, $1 \mathrm{mM}$ EDTA, $10 \%(\mathrm{v} / \mathrm{v})$ glycerol in phosphate buffered saline (PBS), pH 7.4) for $12 \mathrm{~h}$; (2) buffer C (2 M urea, 1 mM EDTA, 10\% (v/v) glycerol, in PBS, pH 7.4) for $12 \mathrm{~h}$; (3) buffer D (1 M urea, 1 mM EDTA, 10\% (v/v) glycerol, in PBS, pH 7.4) for $12 \mathrm{~h}$; and (4) buffer E (PBS, 0.2 g/L KCl, 3.63 g/L Na $\mathrm{HPO}_{4}-12 \mathrm{H}_{2} \mathrm{O}, 0.24 \mathrm{~g} / \mathrm{L} \mathrm{KH}_{2} \mathrm{PO}_{4}, 8 \mathrm{~g} / \mathrm{L} \mathrm{NaCl}$, $\mathrm{pH}$ 7.4) for $12 \mathrm{~h}$, twice.

The buffers used in the purification process were all passed through $0.22 \mu \mathrm{m}$ filter membrane (Millipore, Billerica, USA), and the protein samples collected from each purification step was similarly filtered.

\section{Assay of protein concentration and purity}

The concentration of each protein sample was determined using the Bradford method (Bradford 1976) (Commassie Blue Staining Kit, Solarbio, Beijing, China). Especially, to ensure the reliability of results, the samples with $8 \mathrm{M}$ urea or $7 \mathrm{M}$ guranidine- $\mathrm{HCl}$ were diluted 5 to 10 fold with PBS. And the concentration was found to be linear in relation to the absorbance reading in spectrophotometer (UV7504, XINMAO, Shanghai, China).

The purity of recombinant protein vaccine was determined by $12 \%$ SDS-PAGE. Gel was stained using $0.1 \%(\mathrm{w} / \mathrm{v})$ Coomassie brilliant blue R250 for 20 min, then destained using $10 \%(\mathrm{v} / \mathrm{v})$ methanol with $10 \%(\mathrm{v} / \mathrm{v})$ acetic acid for $4-12 \mathrm{~h}$. The purity of 
the samples was determined by scanning the processed SDS-PAGE gel and using Gel Imager (ExCell Bio, Shanghai, China) for analysis.

The final purity of recombinant vaccine was also determined by HPLC with an Agilent 1100 system (Agilent Technologies, USA), equipped with a quarternary pump, thermostat compartment for the column and photodiode array detector. The chromatographic column was Hypersil ODS2 (250 mm×4.6 mm). The HPLC analysis was done at room temperature. A $20 \mu \mathrm{L}$ aliquot of sample was injected and then eluted with the mobile phase of acetonitrile and $0.1 \%$ trifluoroacetic acid (TFA) gradient at an isocratic flow rate of $1 \mathrm{~mL} / \mathrm{min}$ with a total runtime of $15 \mathrm{~min}$. When $0-10 \mathrm{~min}$, the ratio of acetonitrile with $0.1 \%$ TFA increased from $0 \%$ to $70 \%$, and fell back to $0 \%$ at $14 \mathrm{~min}$. Detection wavelength for protein samples was set at $280 \mathrm{~nm}$.

\section{Western blot analysis}

For Western blot analysis, the proteins separated in the SDS-PAGE were transferred to a nitrocellulose membrane (Burnertte 1981), which was then incubated with polyclonal rabbit anti-his antiserum (Santa Cruz, USA) at a 1:500 dilution. After incubation with horseradish-peroxidase-conjugated anti-rabbit IgG (1:2000 dilution), an ECL Advance Western Blotting Detection Kit (GE, USA) was used for visualization of target protein.

\section{Simple preparation of purified and renatured vaccine protein}

The refolded protein vaccine was precooled with $5 \%$ mannitol at $-40{ }^{\circ} \mathrm{C}$, then lyophilized at $-60^{\circ} \mathrm{C}$ by vacuum freeze dryer (LGJ-12, SONGYUAN, Beijing, China). 


\section{Assay of host protein and endotoxin in purified protein vaccine}

Host protein and endotoxin were determined by following the method as described in Appendix IX C and XII E of Part 3 in 2010 edition of Chinese pharmacopeia, respectively.

\section{Immunogenicity assay of recombinant vaccine}

Twenty predicted HLA DRB1 class-II restricted HIV-1 epitopes were synthesized by GL Biochem (Shanghai) Ltd. and used in the ELIspot assay. The amino acid sequence of each peptide was described previously (Shu et al. 2014).

Male and female Balb/c mice of 6-8 weeks were immunized subcutaneously in the base-of-tail with $100 \mu \mathrm{L}$ of recombinant vaccine and $2 \%$ Alhydrogel adjuvant (Invivogen, USA) mixed at 1:1 ratio. Control mice were immunized with $100 \mu \mathrm{L}$ of PBS and Alhydrogel mixture. Each mouse received 3 immunizations at weeks 0, 2 and 4. Their spleen cells were then harvested for the ELIspot assay.

ELIspot assay was performed using 96-well-PVDF plates (Millipore, USA) which were coated overnight at $4{ }^{\circ} \mathrm{C}$ with $10 \mu \mathrm{g} / \mathrm{ml}$ of primary anti-IFN- $\gamma$ mAb (Mabtech, Sweden). The antibody coated plates were washed five times with PBS and blocked with RPMI 1640 containing 10\% fetal bovine serum (FBS) for $1 \mathrm{hr}$ at $37^{\circ} \mathrm{C}$. Plates were washed 5 times with PBS again. Murine spleen mononuclear cells (MNCs) were isolated and then treated with ACK lysis buffer to remove RBCs prior to stimulation with peptides. MNC at $3 \times 10^{5}$ cells per well were plated in duplicate wells, and then $2 \mathrm{ng}$ of individual peptides was added to each well. After 30 hours of 
stimulation, plates were washed 5 times. Biotinylated anti-IFN- $\gamma$ mAb $(2 \mu \mathrm{g} / \mathrm{mL})$ (R46A2) was added to each well and then incubated for $2 \mathrm{~h}$. The plates were then washed 5 times followed by $1 \mathrm{~h}$ incubation with Streptavidin-Alkaline Phosphatase (1 $\mu \mathrm{g} / \mathrm{mL})$. The reaction was stopped by adding $100 \mu \mathrm{L} \mathrm{ddH}_{2} \mathrm{O}$ to each well. The spots were enumerated using CTL ImmunoSpot Software and BioSpot Colony Counting Software.

\section{Results and Discussion}

\section{Cloning and expression of the recombinant protein}

The target DNA segment was inserted into pET-30a vector and the recombinant plasmid was successfully transformed into E. coli BL21 (DE3) cells. Recombinant plasmid extracted from positive colonies was successfully constructed as confirmed by restriction enzyme digestion (Fig. 1) and DNA sequencing (Fig. 2).

The transformed E. coli BL21 (DE3) cells were cultivated and induced with 0.1 mM IPTG in LB medium at $37^{\circ} \mathrm{C}$, whereas the control was not induced. The protein profiles of control and induced cells were analyzed on 12\% SDS-PAGE. The expression of recombinant target protein was observed with the molecular mass of 39 $\mathrm{kDa}$ in induced cell pellets, and absent in controls (Fig. 3A). As expected, the recombinant protein vaccine was almost exclusively expressed as inclusion bodies. To optimize the conditions for expression of soluble fraction of the recombinant protein 
vaccine, various IPTG concentrations and induction temperatures were assessed. However, the fraction of target proteins expressed in the form of inclusion bodies was unchanged. Thus $0.1 \mathrm{mM}$ IPTG induction at $37^{\circ} \mathrm{C}$ was chosen as the optimal condition for obtaining inclusion bodies. Western blot was carried out with anti-his-tag monoclonal antibody $(\mathrm{mAb})$. The result showed that the target protein reacted with the anti-his-tag mAb (Fig. 3B).

\section{Denaturation of inclusion bodies}

In the standard protocol, either $6 \mathrm{M}$ guanidine hydrochloride or $8 \mathrm{M}$ urea was used to denature the inclusion bodies. However, in the present study, the recombinant protein vaccine expressed as inclusion body was difficult to dissolve in $6 \mathrm{M}$ guanidine hydrochloride or $8 \mathrm{M}$ urea, even $10 \mathrm{M}$ urea. Thus, higher concentration of guanidine hydrochloride was used. We found that most of inclusion bodies were denatured in $7 \mathrm{M}$ guanidine hydrochloride, and a further increase in concentration did not improve the efficiency further. On the contrary, high concentration of guanidine hydrochloride impaired the ion-exchange chromatography (IEC) and resulted in less efficient renaturation. Unfortunately, almost all of the recombinant protein vaccine that dissolved in $7 \mathrm{M}$ guanidine hydrochloride was precipitated during the refolding process. To solve this problem, attempts were made to dialyze the denatured proteins into milder condition of $8 \mathrm{M}$ urea, instead of $7 \mathrm{M}$ guanidine hydrochloride. We found that the proteins remained stably dissolved in $8 \mathrm{M}$ urea without precipitation, and this process led to greater renaturation efficiency. The reason might be that the denatured inclusion bodies in $7 \mathrm{M}$ guanidine hydrochloride were gradually refolded to a more stable 
configuration in the milder condition of $8 \mathrm{M}$ urea.

In order to further simplify the denaturation procedures, the inclusion bodies dissolved in $7 \mathrm{M}$ guanidine hydrochloride were gently diluted with $8 \mathrm{M}$ urea until the concentration of guanidine hydrochloride was reduced to $1 \mathrm{M}$. As a result, not only the inclusion bodies were kept dissolved, possibly with a stable protein conformation in the denaturation conditions, but low concentration of guanidine hydrochloride did not impede the purification process.

\section{Purification and refolding of proteins obtained from inclusion bodies}

$\mathrm{Ni}^{2+}$ affinity chromatography with Ni Sepharose Fast Flow was employed to purify the target protein. Dissolved his-tagged recombinant protein was bound to the $\mathrm{Ni}^{2+}$ chelated beads. A series of imidazole concentrations (100-500 mM) was used to elute the protein, but no significant differences were found among various concentrations of imidazole. Thus, $500 \mathrm{mM}$ imidazole was used to elute all bound protein for crude purification (Fig. 4). The results showed that the purity of target proteins was greatly improved. Due to the non-specific adsorption, one-step purification could not be carried out by HisTrap FF column. Therefore, proteins in elution buffer of lanes 6-11 were collected for the further purification.

The proteins collected from HisTrap FF column were well precipitated with $30 \%$ saturation $\left(\mathrm{NH}_{4}\right)_{2} \mathrm{SO}_{4}$. Then, attempts were made to further purify the proteins using ammonium sulphate fractional precipitation and hydrophobic chromatography methods, both of which failed to improve the purity of proteins. In order to separate the impurities from desired target protein, further purification was carried out by 
ion-exchange chromatography with CM Sepharose Fast Flow.

After precipitation with $30 \%$ saturation $\left(\mathrm{NH}_{4}\right)_{2} \mathrm{SO}_{4}$ and centrifugation, the proteins were redissolved in buffer A to remove imidazole which reduced the efficiency of ion-exchange chromatography. The redissolved proteins were loaded onto the IEC column and eluted with a linear gradient of $0.1-1 \mathrm{M} \mathrm{NaCl}$ in buffer A. The results showed that almost all bound proteins were eluted with $100-200 \mathrm{mM} \mathrm{NaCl}$ and the purity of target protein was slightly improved to $92 \%$. Thus, proteins with higher purity in lanes 4-8 were collected for further purification (Fig. 5).

In general, more stringent requirement is needed for purification of protein with higher purity. Therefore, further purification was performed using Ni-chelating affinity chromatography containing Ni Sepharose High Performance with higher resolution. Similar to the process of HisTrap FF, the bound proteins were eluted with 100-500 mM imidazole in buffer A. The results showed that most fractions of the recombinant protein vaccine were bound onto HisTrap HP and target proteins with higher purity (more than 95\%) were eluted by buffer A containing $100 \mathrm{mM}$ imidazole. Hence, proteins eluted with $100 \mathrm{mM}$ imidazole were collected for renaturation (Fig. 6).

Through stepwise dialysis using refolding buffer containing 4, 2, 1 and $0 \mathrm{M}$ urea, the recombinant HIV vaccine was successfully dissolved in PBS. The yield of the refolded recombinant vaccine was approximately $90 \%$, which indicated that folding intermediates were smoothly refolded to a stable protein structure. The purity of the refolded proteins was more than $95 \%$ and the yield was $43 \mathrm{mg} / \mathrm{L}$ of fermentation medium (Table 1). After lyophilization with 5\% mannitol, the refolded polypeptide 
HIV vaccine was dried to white powder.

\section{Assay of final purity by HPLC}

To further quantify the purity of recombinant vaccine, HPLC analysis was used. The results showed that the retention time of vaccine protein $(0.2 \mathrm{~g} / \mathrm{L})$ was about $10.006 \mathrm{~min}$ and the peak area of vaccine protein accounted for 95.3\% (Fig. 7), indicating the purified vaccine protein reached a purity of $95.3 \%$.

\section{Assay of host protein (HCP) and endotoxin in prepared protein vaccine}

According to the corresponding methods described in Chinese pharmacopeia, the residue of $\mathrm{HCP}$ and endotoxin were determined as $0.17 \mathrm{ng}$ per $\mathrm{mg}$ protein and 0.75 EU per mg protein, respectively. Clearly, the residue of HCP and endotoxin were within the safety range for use in humans. These data further verified the feasibility and reliability of the whole process of purification.

\section{Immunogenicity assay of recombinant vaccine}

To test whether the purified protein vaccine remain functional, we used it to immunize mice. ELISpot assay results showed that 4 epitopes within the vaccine (Pol892, Gag297t, Gag297s, and Gag272) stimulated significant T cell responses in male mice (Fig. 8A). In female mice, not only the same 4 epitopes, but also Gag67 stimulate appreciable T cell response as detected by INFgamma secretion (Fig. 8B). These results demonstrate that protein vaccine purified through the above described process retained antigenicity and immunogenicity. 


\section{Conclusions}

This paper shows different solubilization conditions of the recombinant protein HIV vaccine expressed as inclusion bodies in E. coli, and a three-step purification process under denaturing conditions followed by stepwise dialysis for renaturation. Furthermore, protein vaccine that went through these processes remained antigenic and immunogenic.

Our results demonstrate that the proteins extracted from dissolved inclusion bodies maintain a more stable structure in $8 \mathrm{M}$ urea after being treated with a harsher condition of $7 \mathrm{M}$ guanidine hydrochloride, and this milder denaturing condition might have contributed to the more efficient refolding of the recombinant protein HIV vaccine. After sequential purification by HisTrap FF, CM FF and HisTrap HP, the recombinant protein HIV vaccine has reached a purity of $95 \%$, with a total protein recovery rate of $13 \%$. Moreover, the purified protein product retains its desire functional protein as an immungen. The high purity and high yield are amenable to large scale production, and the products generated by our described methods will facilitate the experimental testing of this candidate polypeptide HIV vaccine and enable the development of a CD4+ T cell vaccine especially catered for Chinese.

\section{Acknowledgement}

We thank Xinxin Lv for discussions and technical support. This work was supported by a grant from the National Major Science and Technology Projects of China (Grant No. 2012ZX10001002-002-002). 


\section{Conflict of interest}

The authors declare that they have no conflict of interest.

\section{References}

Barouch, D.H., Stephenson, K.E., Borducchi, E.N., Smith, K., Stanley, K., McNally, A.G., Liu, J.Y., Abbink, P., Maxfield, L.F., Seaman, M.S., Dugast, A.S., Alter, G., Ferguson, M., Li, W.J., Earl, P.L., Moss, B., Giorgi, E.E., Szinger, J.J., Eller, L.A., Billings, E.A., Rao, M., Tovanabutra, S., Sanders-Buell, E., Weijtens, M., Pau, M.G., Schuitemaker, H., Robb, M.L., Kim, J.H., Korber, B.T., and Michael, N.L. 2013. Protective efficacy of a global HIV-1 mosaic vaccine against heterologous SHIV challenges in rhesus monkeys. Cell. 155 (3) 531-539. Doi: 10.1016/j.cell. 2013.09. 061.

Bradford, M.M. 1976. A rapid and sensitive method for the quantitation of microgram quantities of protein utilizing the principle of protein-dye binding. Anal. Biochem. 72 (1-2): 248-254. Doi: 10.1006/abio.1976.9999.

Buchbinder, S.P., Mehrotra, D.V., Duerr, A., Fitzgerald, D.W., Mogg, R., Li, D., Gilbert, P.B., Lama, J.R., Marmor, M., del Rio, C., McElrath, M.J., Casimiro, D.R., Gottesdiener, K.M., Chodakewitz, J.A., Corey, L., and Robertson, M.N. 2008. Efficacy assessment of a cell-mediated immunity HIV-1 vaccine (the Step Study): a double-blind, randomised, placebo-controlled, test-of-concept trial. The 
Lancet. 372 (9653): 1881-1893. Doi: 10.1016/S0140-6736(08)61591-3.

Bui, H.H., Sidney, J., Peters, B., Sathiamurthy, M., Sinichi, A., Purton, K.A., Mothé, B.R., Chisari, F.V., Watkins, D.I., and Sette, A. 2005. Automated generation and evaluation of specific MHC binding predictive tools: ARB matrix applications. Immunogenetics. 57 (5) 304-314. Doi: 10.1007/s00251-005-0798-y.

Burnertte, W.N. 1981. " Western blotting " : electrophoretic transfer of proteins from sodium dodecyl sulfate-polyacrylamide gels to unmodified nitrocellulose and radiographic detection with antibody and radioiodinate protein A. Anal. Biochem. 112 (2): 195-203. Doi: 10.1016/0003-2697(81)90281-5.

De Groot, A.S., Jesdale, B., Martin, W., Aubin, C.S., Sbai, H., Bosma, A., Lieberman, J., Skowron, G., Mansourati, F., and Mayer, K.H. 2003. Mapping crossclade HIV-1 vaccine epitopes using a bioinformatics approach. Vaccine. 21(21): 4486-4504. Doi: 10.1016/S0264-410X(03)00390-6.

Fischer, W., Perkins, S., Theiler, J., Bhattacharya, T., Yusim, K., Funkhouser, R., Kuiken, C., Haynes, B., Letvin, N.L., Walker, B.D., Hahn, B.H., and Korber, B.T. 2007. Polyvalent vaccines for optimal coverage of potential T-cell epitopes in global HIV-1 variants. Nature Med. 13 (1): 100-106. Doi: 10.1038/nm1461.

Gonzalez-Galarza, F.F., Christmas, S., Middleton, D., and Jones, A.R. 2011. Allele frequency net: a database and online repository for immune gene frequencies in worldwide populations. Nucleic Acids Res. 39 (Database issue): D913-919. Doi: 10.1093/nar/gkq-1128.

Haynes, B.F. 2015. New approaches to HIV vaccine development. Curr. Opin. 
Immunol. 35: 39-47. Doi: 10.1016/j.coi.2015.05.007.

Hulot, S.L., Korber, B., Giorgi, E.E., Vandergrift, N., Saunders, K.O., Balachandran, H., Mach, L.V., Lifton, M.A., Pantaleo, G., Tartaglia, J., Phogat, S., Jacobs, B., Kibler, K., Perdiguero, B., Gomez, C.E., Esteban, M., Rosati, M., Felber, B.K., Pavlakis, G.N., Parks, R., Lloyd, K., Sutherland, L., Scearce, R., Letvin, N.L., Seaman, M.S., Alam, S.M., Montefiori, D., Liao, H.X., Haynes, B.F., and Santra, S. 2015. Comparison of immunogenicity in rhesus macaques of transmittedfounder, HIV-1 group $\mathrm{M}$ consensus and trivalent mosaic Envelope vaccines formulated as a DNA prime, NYVAC and Envelope protein boost. J. Virol. 89 (12): 6462-6480. Doi: 10.1128/jvi.00383-15.

Korber, B.T., Letvin, N.L., and Haynes, B.F. 2009. T-cell vaccine strategies for human immunodeficiency virus, the virus with a thousand faces. J. Virol. 83 (14): 8300-8314. Doi: 10.1128/JVI.00114-09.

Kuiken, C., Korber, B., and Shafer, R.W. 2003. HIV sequence databases. AIDS Rev. 5 (1): 52-61.

Kulkarni, V., Valentin, A., Rosati, M., Alicea, C., Singh, A.K., Jalah, R., Broderick, K.E., Sardesai, N.Y., Le Gall, S., Mothe, B., Brander, C., Rolland, M., Mullins, J.I., Pavlakis, G.N., and Felber, B.K. 2014. Altered response hierarchy and increased T-cell breadth upon HIV-1 conserved element DNA vaccination in macaques. Plos One. 9 (1): 1-13. Doi: 10.1371/journal.pone.0103198.

Laemmli, U.K. 1970. Cleavage of structural proteins during the assembly of the head of bacteriophage T4. Nature. 227 (5259): 680-685. Doi: 10.1038/227680a0. 
Létourneau, S., Im, E.J., Mashishi, T., Brereton, C., Bridgeman, A., Yang, H.B., Dorrell, L., Dong, T., Korber, B., McMichael, A.J., and Hanke, T. 2007. Design and pre-clinical evaluation of a universal HIV-1 vaccine. Plos One. 2 (10): 1-11. Doi: 10.1371/annotation/ fca26-a4f-42c1-4772-a19e-aa9d96c4eeb2.

Lu, Q., Hao, P., Curcin, V., He, W.Z., Li, Y.Y., Luo, Q.M., Guo, Y.K., and Li, Y.X. 2006. KDE bioscience: platform for bioinformatics analysis workflows. J. Biomed. Inform. 39 (4): 440-450. Doi: 10.1016/j.jbi.2005.09.001.

McElrath, M.J., De Rosa, S.C., Moodie, Z., Dubey, S., Kierstead, L., Janes, H., Defawe, O.D., Carter, D.K., Hural, J., Akondy, R., Buchbinder, S.P., Robertson, M.N., Mehrotra, D.V., Self, S.G., Corey, L., Shiver, J.W., and Casimiro, D.R. 2008. HIV-1 vaccine induced immunity in the test-of-concept Step Study: a case-cohort analysis. The Lancet. 372 (9653): 1894-1905. Doi: 10.1016/S0140$6736(08) 61592-5$.

Mcmichael, A.J., Borrow, P., Tomaras, G.D., Goonetilleke, N., and Haynes, B.F. 2010. The immune response during acute HIV-1 infection: clues for vaccine development. Nat. Rev. Immunol. 10 (1): 11-23. Doi: 10.1038/nri2674.

Mothe, B., Hu, X.T., Llano, A., Rosati, M., Olvera, A., Kulkarni V., Valentin, A., Alicea, C., Pilkington, G.R., Aardesai, N.Y., Rocafort, M., Crespo, M., Carrillo, J., Marco, A., Mullins, J.I., Dorrell, L., Hanke, T., Clotet, B., Pavlakis, G.N., Felber, B.K., and Brander, C. 2015. A human immune datainformed vaccine concept elicits strong and broad T-cell specificities associated with HIV-1 control in mice and macaques. J. Transl. Med. 13 (1): 1-23. Doi: 10.1186/s12967-015- 
0392-5.

Nielsen, M., and Lund, O. 2009. An artificial neural network-based alignment algorithm for MHC class II peptide binding prediction. BMC Bioinformatics. 10 (1): 1-10. Doi: 10.1186/1471-2105-10-296.

Nielsen, M., Lundegaard, C., Blicher, T., Peters, B., Sette, A., Justesen, S., Buus, S., and Lund, O. 2008. Quantitative predictions of peptide binding to any HLA-DR molecule of known sequence: NetMHCIIpan. Plos Comput. Biol. 4 (7):: e1000107. Doi: 10.1371/ journal.pcbi.1000107.

Nielsen, M., Lundegaard, C., and Lund, O. 2007. Prediction of MHC class II binding affinity using SMM-align, a novel stabilization matrix alignment method. BMC Bioinformatics. 8 (27): 238. Doi: 10.1186/1471-2105-8-238.

Shu, J.Y., Fan, X.J., Ping, J., Jin, X., and Hao, P. 2014. Designing Peptide-Based HIV Vaccine for Chinese. Biomed. Res. Int. 2014(1): 1153-1166. Doi: 10.1155/ $2014 / 272950$.

Sturniolo, T., Bono, E., Ding, J.Y., Raddrizzani, L., Tuereci, O., Sahin, U., Braxenthaler, M., Gallazzi, F., Protti, M.P., Sinigaglia, F., and Hammer, J. 1999. Generation of tissuespecific and promiscuous HLA ligand databases using DNA microarrays and virtual HLA class II matrices. Nat. Biotechnol. 17 (6): 555-561. Doi: $10.1038 / 9858$.

van der Kuyl, A.C., and Berkhout, B. 2012. The biased nucleotide composition of the HIV genome: a constant factor in a highly variable virus. Retrovirology. 9 (1): 1-14. Doi: 10.1186/1742-4690-9-92. 
Vita, R., Zarebski, L., Greenbaum, J.A., Emami, H., Hoof, I., Salimi, N., Damle, R., Sette, A., and Peters, B. 2010. The immune epitope database 2.0. Nucleic Acids Res. 38 (Suppl 1): 854-862. Doi: 10.1093/nar/gkp1004.

Walker, B.D., and Burton, D.R. 2008. Toward an AIDS vaccine. Science. 320 (5877): 760-764. Doi: 10.1126/science.1152622.

Walker, L.E., Vang, L., Shen, X.F., Livingstona, B.D., Post, P., Sette, A., Steven Godin, C., and Newman, M.J. 2009. Design and preclinical development of a recombinant protein and DNA plasmid mixed format vaccine to deliver HIV-derived T-lymphocyte epitopes. Vaccine. 27 (50): 7087-7095. Doi: 10.1016/j.vaccine. 2009.09.059.

Wang, P., Sidney, J., Kim, Y., Sette, A., Lund, O., Nielsen, M., and Peters, B. 2010. Peptide binding predictions for HLA DR, DP and DQ molecules. BMC Bioinformatics. 11 (1): 1-12. Doi: 10.1186/1471- 2105-11-568. 


\section{Table}

Table 1

Enrichment of HIV vaccine fusion protein after each step of the purification procedure.

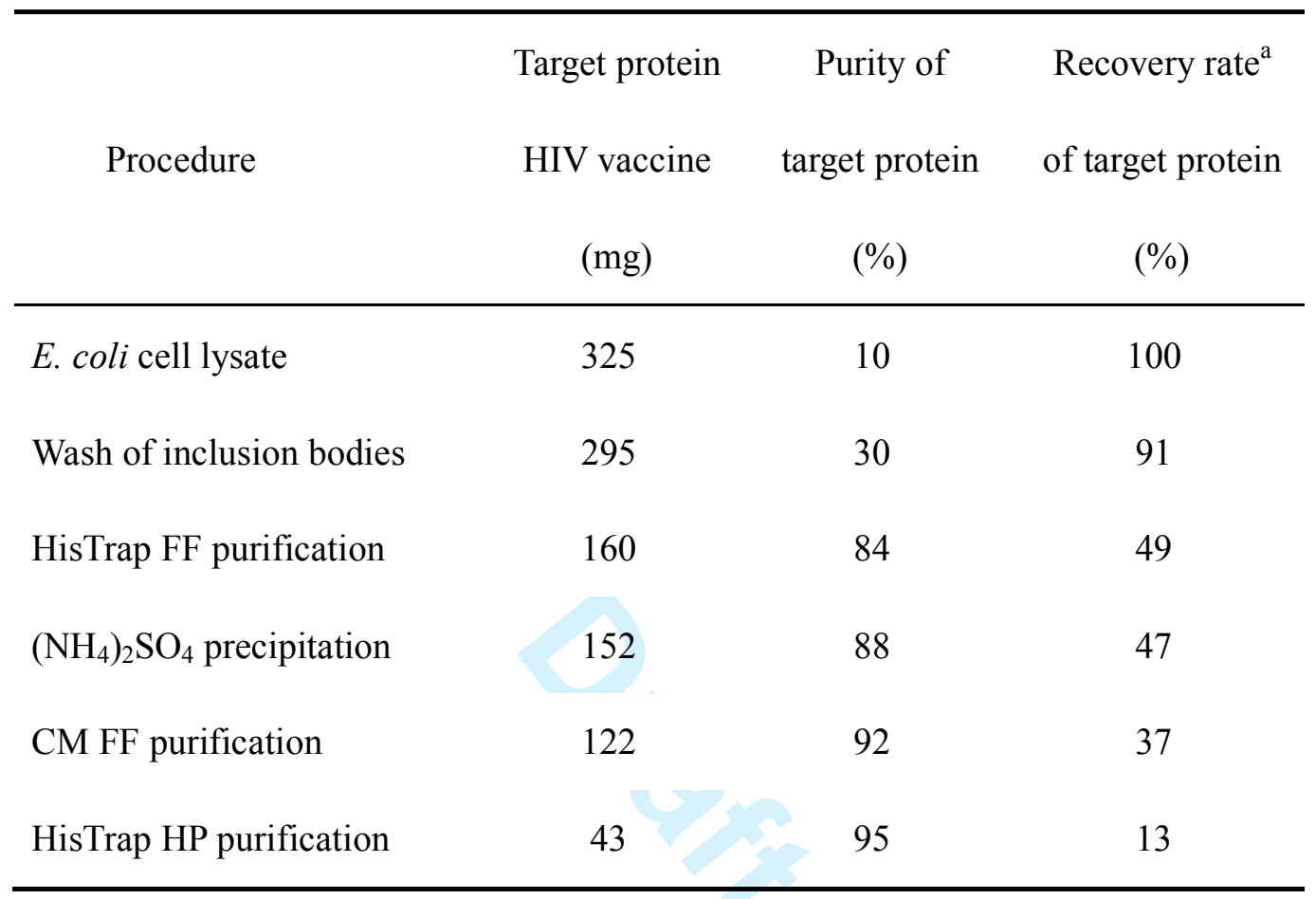

${ }^{a}$ The recovery rate was the final recovery rate by the corresponding step. 


\section{Figures captions}

Fig. 1. Restriction enzyme digestion of recombinant expression plasmids. M: DNA marker; lane 1 and 2: restriction digestion of recombinant plasmids with EcoR I and Not I.

Fig. 2. DNA sequence of HIV vaccine protein. The underlined sequences were endonuclease site sequences of EcoR I (above) and Not I (below), respectively.

Fig. 3. Expression analysis of recombinant HIV vaccine by SDS-PAGE and Western blot. (A) Expression analysis by SDS-PAGE. Lane 1 and 2: supernatant and pellet of control cell lysates; lane 3 and 4: supernatant and pellet of induced cell lysates. The arrow indicates the location of HIV vaccine. (B) Samples on (A) were blotted with anti-his-tag mAbs. The arrow indicates the confirmation of anti-his-tag mAb staining.

Fig. 4. $\mathrm{Ni}^{2+}$-chelating affinity chromatography (HisTrap FF) analysis by SDS-PAGE. Denatured inclusion bodies were loaded onto HisTrap FF column. Lane 1: denatured protein samples; lane 2: unbound fractions; lane 3-11: fractions eluted with $500 \mathrm{mM}$ imidazole in elution buffer; M: protein molecular weight marker. The arrow indicates the location of HIV vaccine.

Fig. 5. Fractions collected from Ion-exchange chromatography (CM FF) were analyzed by SDS-PAGE. The redissolved proteins from ammonium sulphate 
precipitation were loaded onto $\mathrm{CM}$ cation exchange column. M: protein molecular weight marker; lane 1: protein samples; lane 2: unbound fractions; lane 3 and 4: fractions eluted with $100 \mathrm{mM} \mathrm{NaCl}$ in elution buffer; lane 5 and 6 : fractions eluted with $150 \mathrm{mM} \mathrm{NaCl}$; lane 7: fractions eluted with $200 \mathrm{mM} \mathrm{NaCl}$; lane 8: fractions eluted with $1 \mathrm{M} \mathrm{NaCl}$. The arrow indicates the location of HIV vaccine.

Fig. 6. Fractions collected from Ni-chelating affinity chromatography (HisTrap HP) were analyzed by SDS-PAGE. Proteins eluted from CM cation exchange column were loaded onto HisTrap HP column. Lane 1: protein samples eluted from CM FF; lane 2: unbound fractions; lane 3 and 4: fractions eluted with $100 \mathrm{mM}$ imidazole in elution buffer; lane 5 and 6: fractions eluted with $200 \mathrm{mM}$ imidazole; lane 7 and 8: fractions eluted with $500 \mathrm{mM}$ imidazole. The arrow indicates the location of HIV vaccine.

Fig. 7. Chromatogram of purified recombinant vaccine. The retention time of vaccine protein was about 10.006 min. The arrow indicates the peak of HIV vaccine.

Fig. 8. Immunogenicity of recombinant protein vaccine. Male (A) and female (B) mice were immunized with $10 \mu \mathrm{g}$ of recombinant vaccine for 3 times at weeks $0,2,4$. The spleen cells were harvested and used for ELIspot assay with stimulation by individual peptide as indicated. Results were expressed as spot forming cells (SFC) per million splenocytes from 3 controls and 5 immunized mice. Bars indicate mean and standard deviation. 


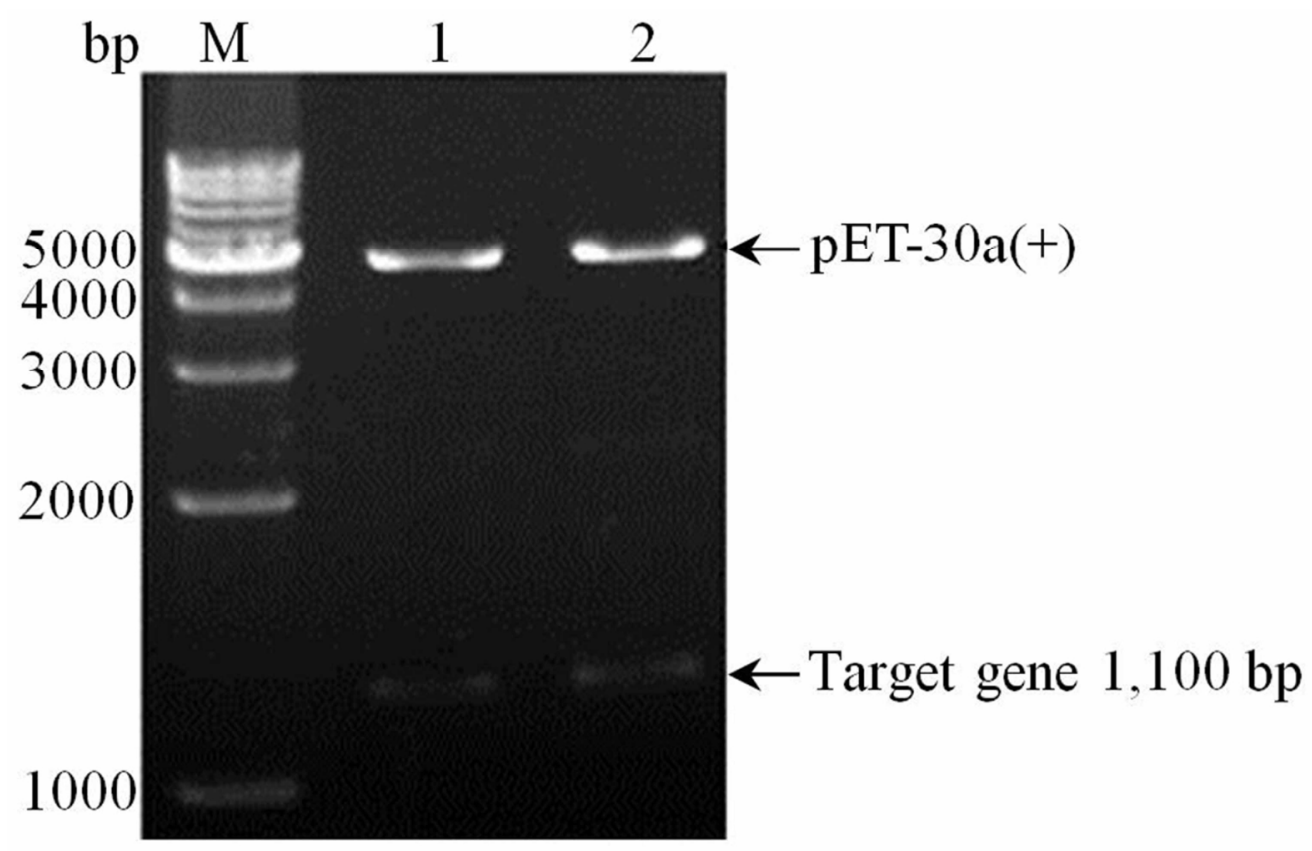

Fig. 1. Restriction enzyme digestion of recombinant expression plasmids. M: DNA marker; lane 1 and 2 : restriction digestion of recombinant plasmids with EcoR I and Not I.

$166 \times 107 \mathrm{~mm}(300 \times 300 \mathrm{DPI})$ 
5 '-atgcaccatcatcatcatcattcttctggtctggtgccacgcggttctggtatgaaagaaaccgctgctgctaaattegaa cgccagcacatggacagcccagatctgggtaccgacgacgacgacaaggecatggetgatatcggatccgaattctgga ttattctgggtctgaataaaattgttcgtatgtatagccegecggttgttagcacccagctgctgetgaatggtagectggcag aagttcagatggcagttttattcataatttaaacgtaaaggtggtctgcgtattattttgcagttctgagcattgttaatcgtgtt cgtattctggatctgtgggtttatcatacccagggttatttccggatctgaataaaattgttcgtatgtatagcccgaccagcatt ctggattggggtattaaacagctgcaggcacgtgttctggcagttgaacgtggtgcatttgatctgagctttttctgaaagaa aaaggtggtctggttgatcgttttataaaacctgcgtgcagaacaggcaacccagggtttccggttcgtccgcaggttcc gctgcgtccgatgacctatacccegggtattcgttatcagtataatgttctgccgcagggttgggttgatcgttttataaaacc ctgcgtgcagaacaggcaagccagcgtcagctgctgagcggtattgttcagcagcagagcaatctgctgggtctgatttat agcaaaaaacgtcaggaaattctggatctgtggaaaccgtgtgttaaactgaccccgctgtgtgttaccctgaattgttataaa cgttggattattctgggtctgaataaaattgttcgtatgecgetgacctttggttggtgttttaaactggttceggttgatccgtttg gttggtgttttaaactggttccggttgatccgcgtgaagtttgtaaacagattattaaacagctgcagceggcactgcagaccg gtctgtataaatataaagttgttaaaattgaaccgctgggtgttctgtaagcggccgc- 3 '

Fig. 2. DNA sequence of HIV vaccine protein. The underlined sequences were endonuclease site sequences of EcoR I (above) and Not I (below), respectively.

$162 \times 80 \mathrm{~mm}(300 \times 300 \mathrm{DPI})$ 


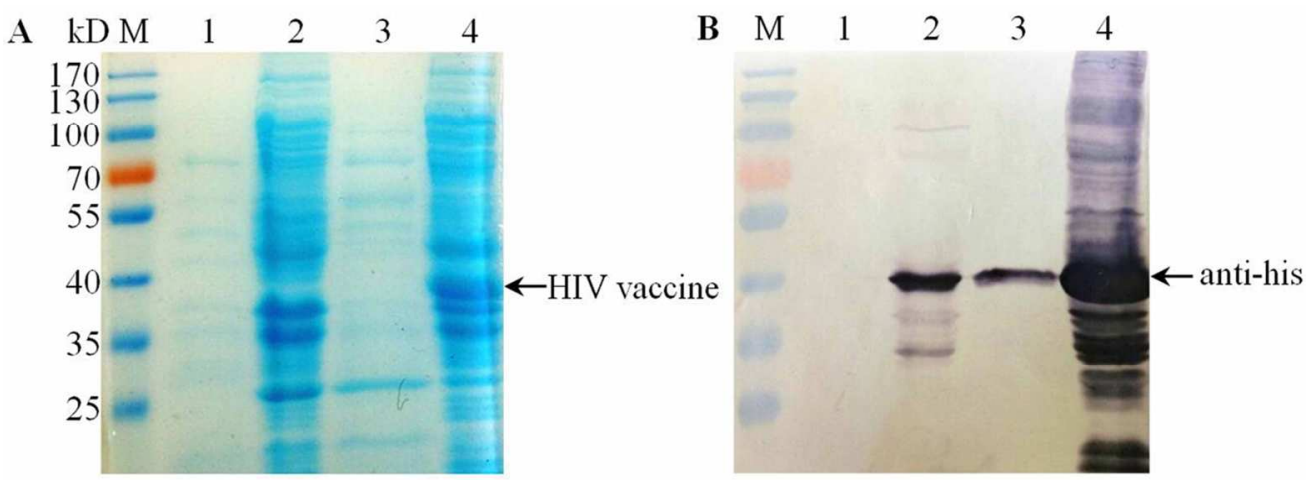

Fig. 3. Expression analysis of recombinant HIV vaccine by SDS-PAGE and Western blot. (A) Expression analysis by SDS-PAGE. Lane 1 and 2: supernatant and pellet of control cell lysates; lane 3 and 4: supernatant and pellet of induced cell lysates. The arrow indicates the location of HIV vaccine. (B) Samples on (A) were blotted with anti-his-tag mAbs. The arrow indicates the confirmation of anti-his-tag mAb staining.

$128 \times 47 \mathrm{~mm}(300 \times 300$ DPI $)$ 


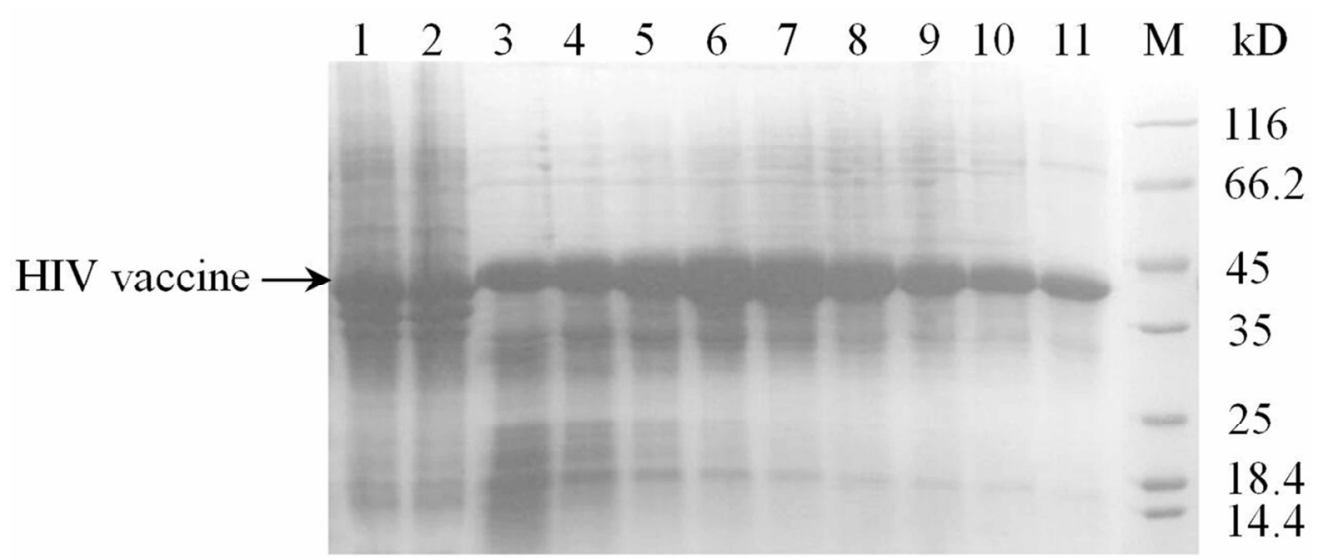

Fig. 4. Ni2+-chelating affinity chromatography (HisTrap FF) analysis by SDS-PAGE. Denatured inclusion bodies were loaded onto HisTrap FF column. Lane 1: denatured protein samples; lane 2: unbound fractions; lane 3-11: fractions eluted with $500 \mathrm{mM}$ imidazole in elution buffer; M: protein molecular weight marker. The arrow indicates the location of HIV vaccine.

$144 \times 61 \mathrm{~mm}(300 \times 300 \mathrm{DPI})$ 


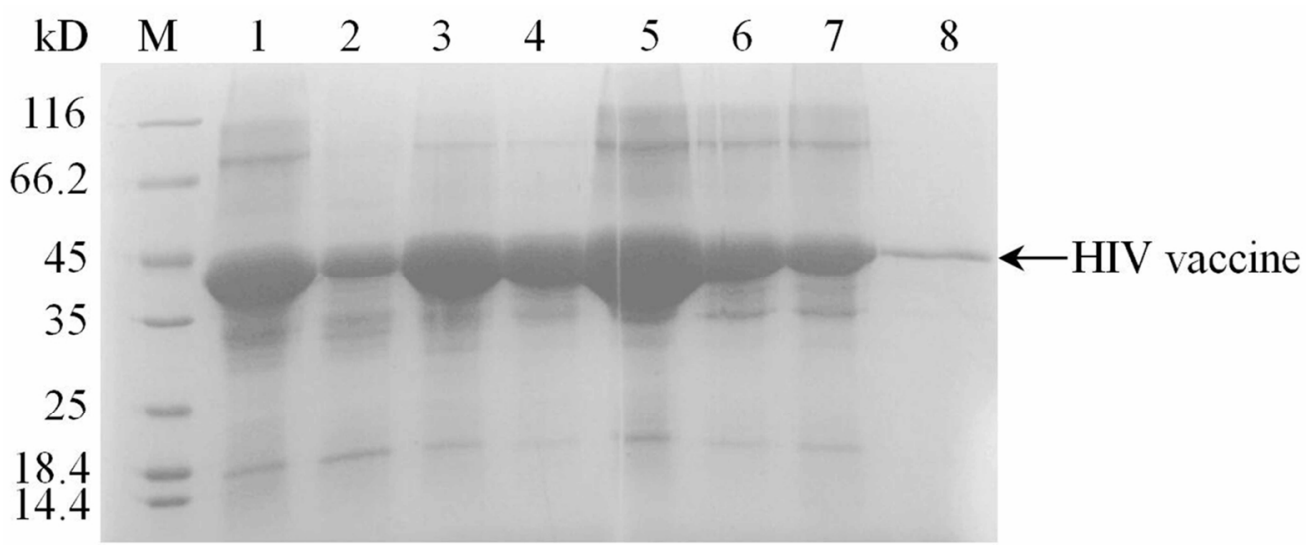

Fig. 5. Fractions collected from Ion-exchange chromatography (CM FF) were analyzed by SDS-PAGE. The redissolved proteins from ammonium sulphate precipitation were loaded onto CM cation exchange column. M: protein molecular weight marker; lane 1: protein samples; lane 2: unbound fractions; lane 3 and 4: fractions eluted with $100 \mathrm{mM} \mathrm{NaCl}$ in elution buffer; lane 5 and 6: fractions eluted with $150 \mathrm{mM} \mathrm{NaCl}$; lane 7: fractions eluted with $200 \mathrm{mM} \mathrm{NaCl}$; lane 8: fractions eluted with $1 \mathrm{M} \mathrm{NaCl}$. The arrow indicates the location of HIV vaccine.

$145 \times 60 \mathrm{~mm}(300 \times 300$ DPI $)$ 


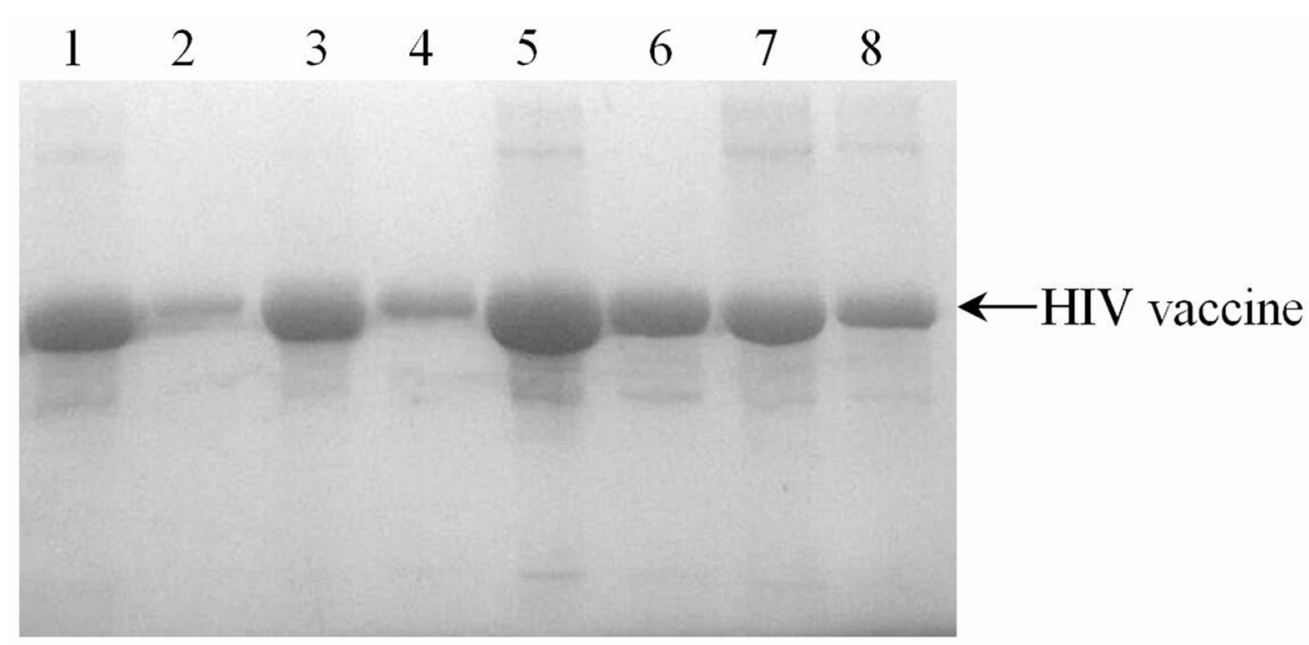

Fig. 6. Fractions collected from Ni-chelating affinity chromatography (HisTrap HP) were analyzed by SDSPAGE. Proteins eluted from CM cation exchange column were loaded onto HisTrap HP column. Lane 1: protein samples eluted from CM FF; lane 2: unbound fractions; lane 3 and 4: fractions eluted with $100 \mathrm{mM}$ imidazole in elution buffer; lane 5 and 6: fractions eluted with $200 \mathrm{mM}$ imidazole; lane 7 and 8: fractions eluted with $500 \mathrm{mM}$ imidazole. The arrow indicates the location of HIV vaccine.

$145 \times 70 \mathrm{~mm}(300 \times 300$ DPI $)$ 


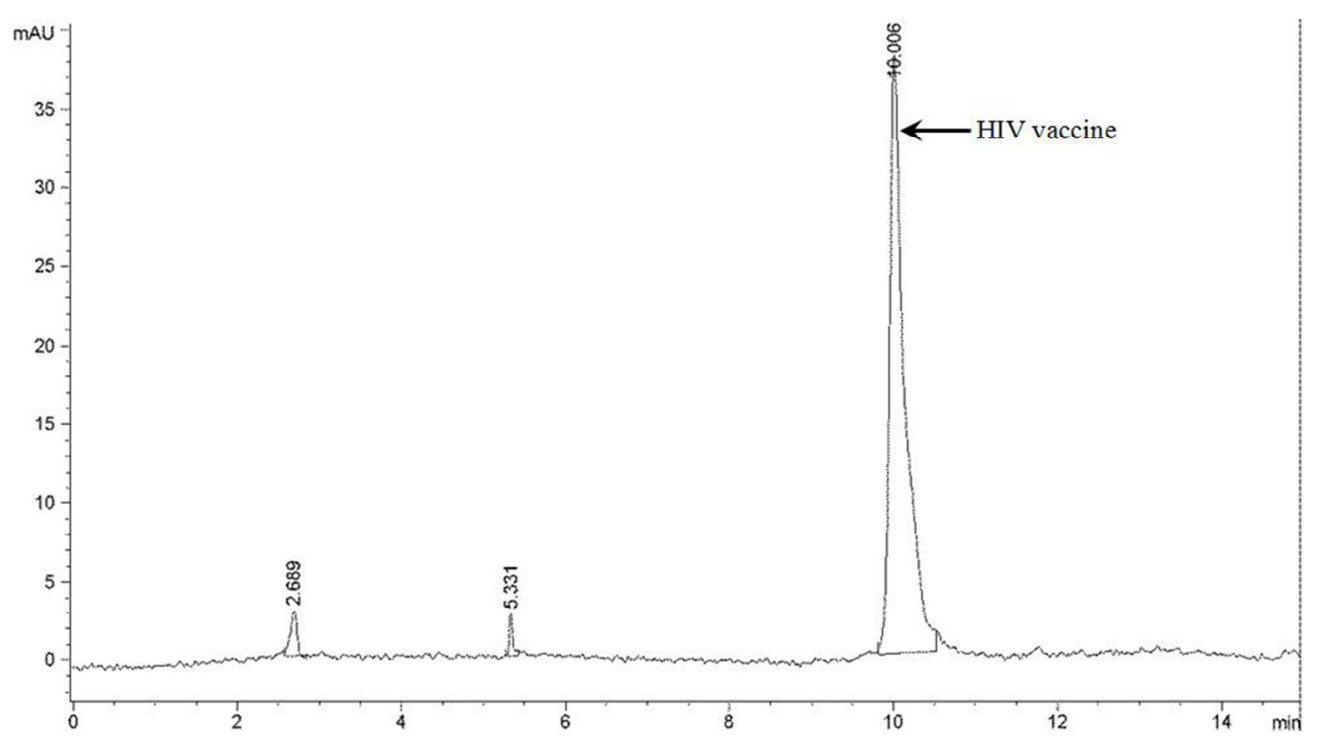

Fig. 7. Chromatogram of purified recombinant vaccine. The retention time of vaccine protein was about $10.006 \mathrm{~min}$. The arrow indicates the peak of HIV vaccine.

$142 \times 78 \mathrm{~mm}(300 \times 300 \mathrm{DPI})$ 

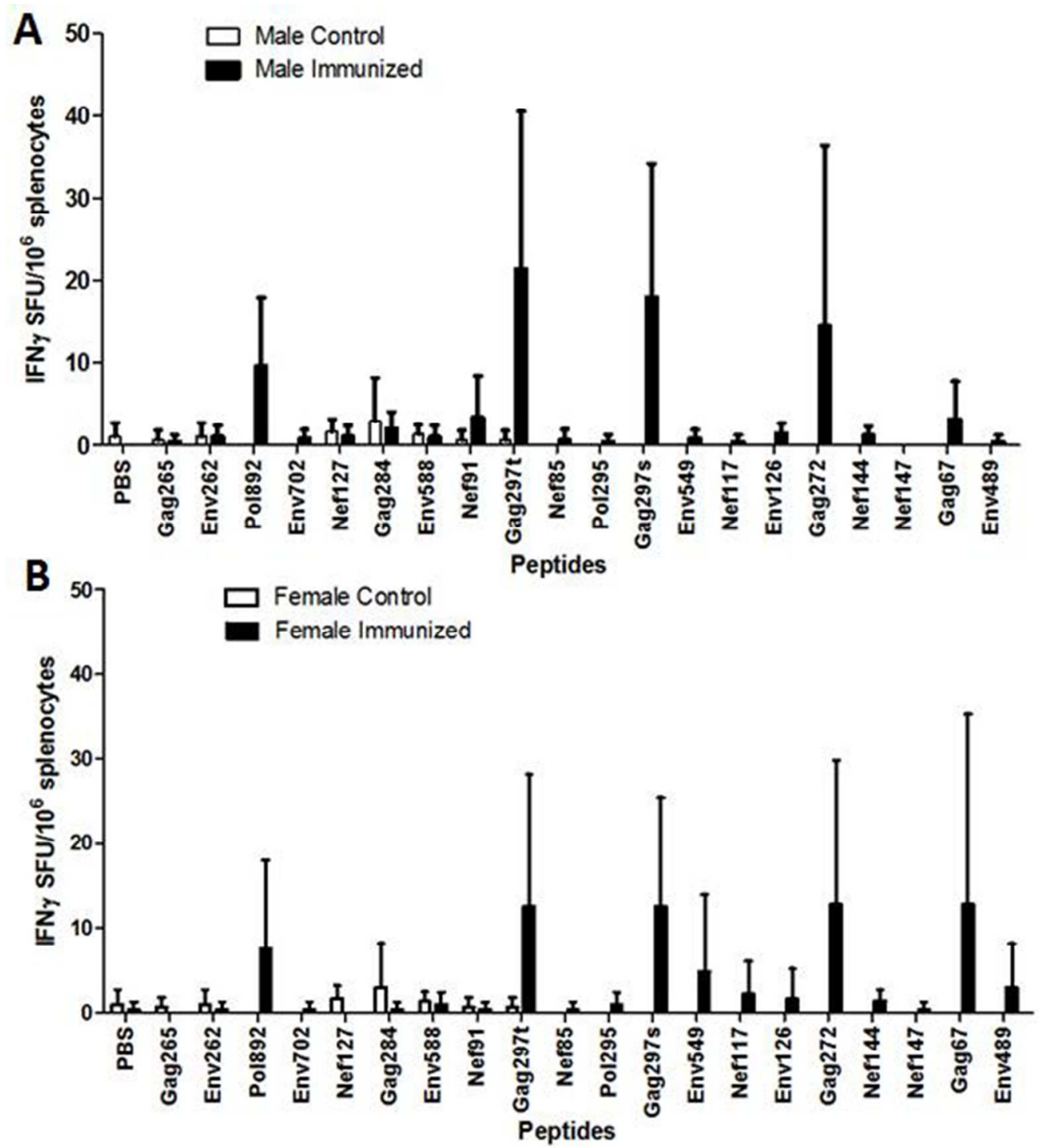

Fig. 8. Immunogenicity of recombinant protein vaccine. Male $(A)$ and female $(B)$ mice were immunized with $10 \mu \mathrm{g}$ of recombinant vaccine for 3 times at weeks $0,2,4$. The spleen cells were harvested and used for ELIspot assay with stimulation by individual peptide as indicated. Results were expressed as spot forming cells (SFC) per million splenocytes from 3 controls and 5 immunized mice. Bars indicate mean and standard deviation.

$166 \times 185 \mathrm{~mm}(300 \times 300$ DPI $)$ 